\title{
Chapter 8 \\ Working Class Condition and Migrant \\ Experience: The Case of Portuguese \\ Construction Workers
}

\author{
João Queirós
}

\subsection{Introduction}

This chapter presents some results of fieldwork-based research into the transformations affecting the professional, geographical and social mobility strategies of construction workers throughout the years of economic and social crisis Portugal faced from the beginning of the 2000s - but especially after 2008. Its main goal was to arrive at an empirical and analytical sociological understanding of these transformations.

Building on the results of previous work on this topic (Pinto and Queiroz 1996a, b; Pinto 1999; Pinto and Queirós 2008, 2010; Queirós 2010; Monteiro 2014a), this research started with a multi-sited ethnography conducted in 2007 and 2008 in three distinct locations: two small communities in Northwest Portugal, where the migration of construction workers to Spain had become a salient aspect of local economic and social relations, and a small city in the Spanish region of Galicia, where a group of Portuguese construction workers was followed and accompanied in its everyday routines (Monteiro and Queirós 2009a, b, 2010; Queirós and Monteiro 2016). In both locations our research sketched the main features and implications of the (changing) work-related mobility of Portuguese construction workers coming from different areas of the northern and especially the northwestern parts of the country. This initial sketch was then followed by a new study based on fieldwork once again in Galicia, in the same city visited in 2008, and in two locations in eastern France and western Germany. This follow-up study was conducted within the research project "Recent emigration trends in Northwest Portugal: the case of construction workers", funded by the Secretary of State for Portuguese Communities, and its main goal was to document the impacts of the

\footnotetext{
J. Queirós $(\bowtie)$

Instituto de Sociologia da Universidade do Porto and Escola Superior de Educação do

Politécnico do Porto, Porto, Portugal

e-mail: jqueiros@letras.up.pt 
2008-2010 financial, economic and social crisis on the life of an important segment of the Portuguese working class.

Since the early 2000s, circular migration to Spain had been the answer for thousands of workers affected by unemployment, low-paid and/or precarious jobs, and the overall lack of professional and social mobility prospects characterising areas in Northwest Portugal where "traditional" activities (textiles and clothing, footwear, wood and furniture, mining, construction) were facing severe constrains (see, for instance, Pinto and Queirós 2010; Pereira 2012; Monteiro 2014a). But the downfall of the Spanish economy and especially of its real-estate and construction sectors after 2008 threw up several new questions for those studying this phenomenon. As the importance of Spain as a work destination for Portuguese construction workers inevitably declined, it became of major interest to understand how these workers were dealing with this country's "crisis" (see Monteiro and Queirós 2009a; Monteiro 2014b; Queirós and Monteiro 2016).

Following our 2007-2008 study, the constitution of two new "sociological observatories" in France and Germany in the 2013-2014 period - as well as our return to the research site in Galicia, Spain - was envisaged as a way of gathering empirical evidence of the reconfiguration of the professional trajectories and workrelated mobility of Portuguese construction workers formerly involved in circular migration to Spain. This chapter will discuss some of the most salient aspects and implications of these workers' migrant experience - as seen in Galicia, Spain, in 2008 and 2013. It will then show - through reference to data collected in the Bourgogne-Franche-Comté region in eastern France - how the new conditions and characteristics of Portuguese working-class migration to central and northern Europe are intertwined with both changing economic and social conditions in Portugal and accelerating processes of (uneven) economic integration within the EU. In fact, while producing new work patterns and work-related mobilities for Portuguese construction workers, the construction sector's significant recent transformations - at both national and European levels - seem to help reinforce the subordinate integration of southern countries' economies and their workers in the European economy.

\subsection{A Brief Note on Method}

Since it focuses on the different physical and social settings where migration is enacted - and on the ordinary practical and bodily experience of migrants - multisited ethnography enables researchers to overcome both the naturalistic and individualistic interpretations of migration typical of common sense discourses, as well as the simplistic second-degree explanations implicit in "push-pull" models 
and "rational choice" theory. It is necessary to identify and scrutinise interactions between the emigrants' social history as incorporated in schemes of thought and action - which Pierre Bourdieu would call their habitus (see, for instance, Bourdieu 1994; Wacquant 2016) - and the objective conditions in which these schemes are actualised and instantiated in practice, and which actually (re)produce migratory acts. This is why "following connections, associations, and putative relationships" which lies at the heart of multi-sited ethnography - is essential for theoretically and analytically reconstructing a social reality, such as circular migration, that is coproduced in multiple geographically dispersed yet socially interconnected locations (Marcus 1995, 97; see also Marcus 1998; Fitzgerald 2006; Holmes 2013). By "following the people", this "circular" or "mobile" ethnography reconstructs the map of a phenomenon that is simultaneously geographical and social. It can thus be envisaged as an ethnography of contemporaneity, since the space-time of the research is created through the reconstitution of actual, effective social relations, allowing for a territorially fragmented object of study to attain a distinct and specific density, character and analytic coherence (Queirós and Monteiro 2016).

Fitzgerald (2006) advocates four methodological strategies that are useful for an ethnographic study such as that proposed here. Firstly, Fitzgerald $(2006,2)$ underlines the importance of direct contact with social agents in their multiple settings so as to "reveal the full scope of the migration experience and its impacts". Fitzgerald continues (2006, 2): "Despite the practical and epistemological problems of multi-sited fieldwork, it offers advantages for gaining access to members of multi-sited networks and explaining the effects of place on a variety of outcomes". Secondly, Fitzgerald $(2006,2)$ refutes the bias of methodological nationalism that frequently characterises migration studies. What multi-sited fieldwork does is to strip off "the national blinders that restrict the construction of the field", thus integrating in the analysis "both sending and receiving country sites". Thirdly, he emphasises the need to historicise migration processes and the constellation of places they interconnect. By deploying an eclectic methodological strategy combining ethnographic fieldwork with local archival work, oral histories and the recovery of results of previous studies - it is possible to turn "the problem of the 'ethnographic present' into historical depth" (Fitzgerald 2006, 2, 12). Finally, Fitzgerald $(2006,3)$ recalls the need to develop "research programs in which ethnographic case studies contribute to the elaboration of migration theories". As he puts it $(2006,16)$, "ethnographers would do well to situate their studies in ways that strengthen claims to both empirical representativeness and theoretical significance". This implies conducting "intensive research in several connected sites selected for their potential theoretical yield": it is not just about "following the people" in their immediate displacement, but also about understanding "the influences of different kinds of boundary crossings and ecologies on their experiences in multiple domains" (Fitzgerald 2006, 20). 


\subsection{Living In-Between: Social and Symbolic Divisions and Everyday Life Among Portuguese Construction Workers in Spain}

\subsubsection{Economic Crisis and Working-Class Migration in Northwest Portugal}

According to official data from the Spanish National Statistics Institute, close to 6.5 thousand Portuguese individuals entered Spain in 2015. This number was $12 \%$ higher than in 2014 and represented the second consecutive year of growth in the number of Portuguese individuals entering their neighbouring country, thus ending a period of sharp decline in this movement from 2008 through 2013. Although far below those registered from 2004 to 2007 - when official data reported an average of 18 thousand new Portuguese arrivals in Spain each year, reaching a peak of 27 thousand in 2007 - the 2015 figures represented the return to a pattern that made Spain one of the most significant destinations for Portuguese emigration (see Figs. 7.1 and 7.2; see also Pinho and Pires 2013; Vidigal 2016).

Resulting from the economic downturn that followed the 2008 financial crisis which affected the majority of Spain's economic activities, and especially the realestate and construction sectors - the sudden decrease in Portuguese workers arriving in Spain ushered in an era that contrasted sharply with the status quo since the first years of the twenty-first century. Especially between 2002 and 2008, these two countries' divergent socio-economic conditions had favoured the consolidation of Spain as a destination for several thousand Portuguese workers looking for better working and living conditions or simply trying to find a job in the midst of the "crisis back home" (Monteiro and Queirós 2009a; Queirós and Monteiro 2016; Pinho and Pires 2013).

Construction workers originating from different parts of the country, but especially from (post-)industrial and rural areas in the Northern and Central regions, made up one of the largest segments of Portuguese immigrants in Spain in those years. Low salaries, unemployment, and the lack of prospects for professional and social mobility all made the thriving Spanish construction sector very attractive for large numbers of Portuguese workers - especially low skilled men, whose migration frequently took the form of weekly or fortnightly international commutes to construction sites in the neighbouring country. The number of Portuguese nationals residing in Spain rose from 71 thousand in 2004 to almost 150 thousand in 2009. To these should be added Portuguese workers commuting to Spain on a weekly or fortnightly basis, who were estimated to number $80-100$ thousand in the Northwest alone. In this period, construction always accounted for more than $40 \%$ of the total number of Spanish jobs held by Portuguese workers (see Figs. 8.1 and 8.2; Monteiro and Queirós 2010; Queirós and Monteiro 2016; see also Byrne 2011). 


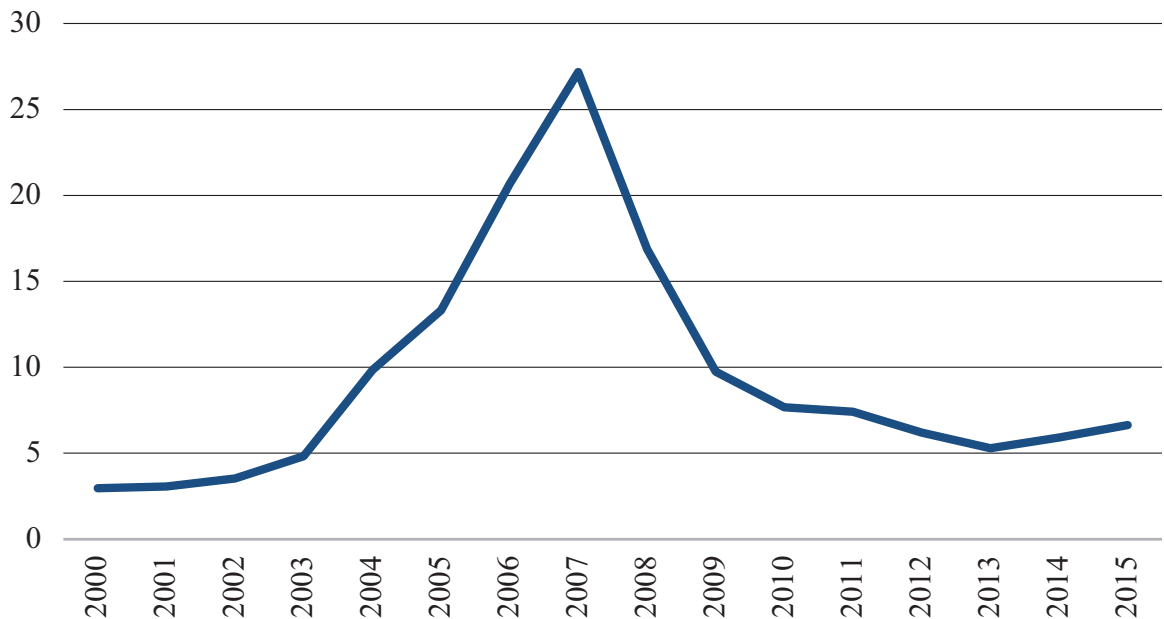

Fig. 8.1 Portuguese entering Spain annually (2000-2015; thousands). Source: Queirós and Monteiro 2016

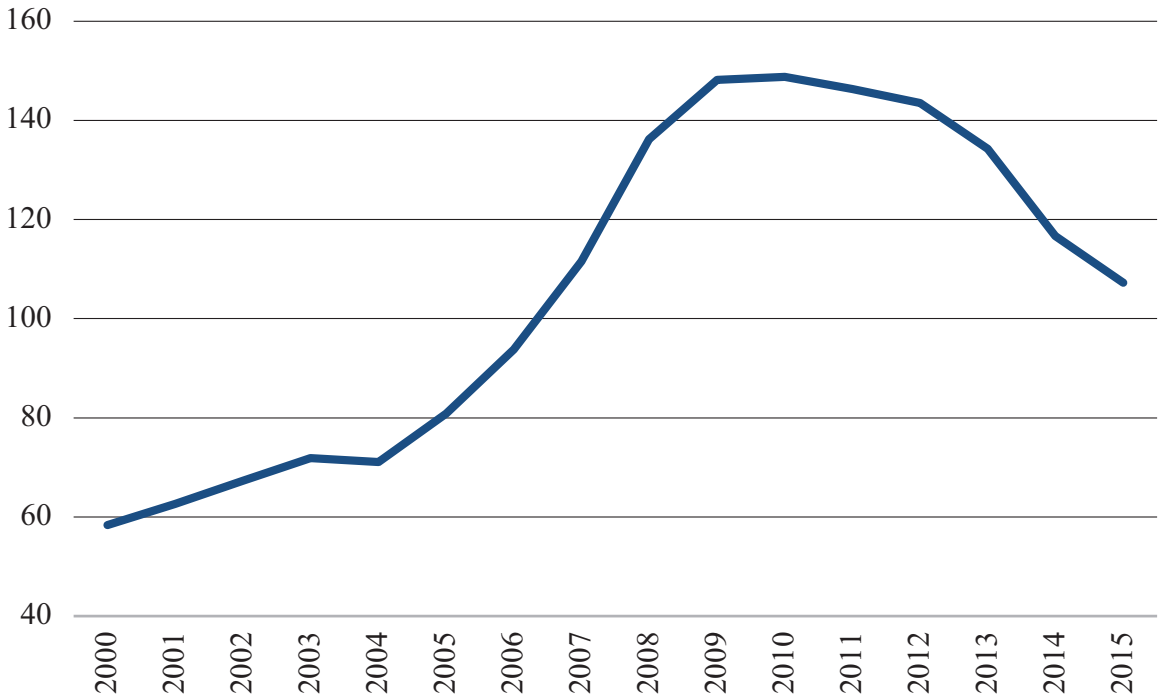

Fig. 8.2 Portuguese-born residents in Spain (2000-2015; thousands).

Source: Queirós and Monteiro 2016

With economic growth "largely driven by a credit-fueled, often speculative expansion in residential house building" (Byrne 2011, 27), and a segmented labour market - albeit with average wages significantly higher than Portugal's - Spain 
became the preferred destination for many Portuguese workers who were either already unemployed or threatened by unemployment. As soon as the "swarm of micro and small subcontractors" prevalent in this sector started to operate on the ground, supply and demand converged. But rather than a supposedly spontaneous process of market equilibrium, the "compatibility between the propensities and interests incorporated in workers, on the one hand, and the objective system of opportunities and demands that encompass the transnational construction labour market, on the other", was in fact intensely promoted by this web of intermediaries, "which simultaneously compete and cooperate among themselves to form a floating, ready-to-use proletariat" (Monteiro 2014b, 11; see also Bosch and Philips 2003). The Spanish construction sector's status as one of the major destinations for north-western Portuguese workers has also been reinforced by the internationalisation strategies of many large Portuguese construction companies, as well as by improvements to infrastructure and transportation that significantly increased the possibility of communication and travel between European regions.

\section{The Growing Importance of Circular Migration}

The increase in circular migration that has been noticed in Portugal since the mid-2000s matches recent global trends in international migration. The intensification of transnational mobility has made this issue "all the rage in international policy circles" (Vertovec 2007, 2). In fact, several international agencies, inter-governmental forums and government departments are putting forward the idea that circular migration represents a "win-win-win" situation, since it brings benefits for both the receiving countries, through meeting labour market shortages, the sending countries, through guaranteeing remittances, and the migrants themselves, through offering employment and control over the use of their wages. As a result, many of these agencies, forums and departments are aiming to promote managed circular migration systems. Although the new policy measures are presented wholly as a way of maximising the developmental potential of circular migration (and of the remittances it generates), it is hard not to see their utility in creating a regulated workforce reserve to meet labour market shortages in specific moments of the economic cycle or in specific activity sectors, while reducing the social costs of permanent immigration and making immigration more amenable to public opinion, especially where there is growing resistance to policies surrounding the permanent accommodation of unskilled migrants (Vertovec 2007, 3-7; see also Burawoy 1976 on the separation migration systems produce between "reproduction of labour force" and "production from labour force"). 


\subsubsection{Social and Symbolic Divisions and Everyday Life Among Portuguese Construction Workers in Spain}

The repeated and long-lasting periods of social and economic constraint experienced by many segments of the Portuguese working classes - especially in the northern part of the country ("the situation in Portugal is very tight") ${ }^{1}-$ lie at the origin of historically specific forms of interest ("I have to turn to somewhere"; "I have to look out for myself"), and thus underpin the formation of aspirations that are plausible because they are probable. Underlying apparently intentional economic "options" and "choices", it is possible to find the personal and collective histories of gradual familiarisation with the kind of social situations that generate the "hunches" and "preferences" justifying the reasonableness of - if not the urge for - certain alternatives ("you have to go"; "you have to make a living"; "you have a good body to work") instead of others ("staying at home"; "doing nothing"; "idling"). Jorge, an 18-year-old who had been working in Spain for over a year when he was interviewed in 2008, puts it in clear terms:

I could have stayed in Portugal, but... you know... Meanwhile, when they asked me to go there [to Spain], I was going to earn a little bit more and I decided to go there. I've looked for jobs back here in Portugal, but there were no immediate proposals, I didn't want to stay at home... and then I decided to go. (...) I needed it back then. I looked in the newspapers, I sent my CV to several companies in Portugal and... (...) Then they offered me this job, I thought over it and, well, it wasn't good for me to stay at home for too long, at home you don't earn money, and then I went.

Insofar as it radically destabilises a "precarious economic balance, shattering the temporal and spatial rhythms that constitute the bonds of all social existence" (Bourdieu and Sayad 1964, 21), temporary or circular migration provides experiences as contradictory as the social conditions on which they are grounded. The "essentialisation" of the relation between spatial (dis)location and social (dis)connection resulting from circular migration - which is aggravated by the characteristics of construction activities - supports and explains the "dualistic view of the world" shared by these workers (Comaroff and Comaroff 1992, 45). From this dualistic view can be deduced the mode of "thinking in pairs" that shapes the discourse of contrast opposing "here" and "there".

The dichotomy of "living in Portugal and working in Spain" provides the axis of articulation for a series of symbolic oppositions juxtaposed to those that are immediately geographical (home versus workplace) and temporal (week versus weekend); Portuguese construction workers in Spain have two worlds of significance, since they have "two lives", the "life there" and the "life here", as Pedro, a 31-yearold working in Spain for over 7 years, puts it. The physical and temporal overinvestment in work, the domestic confinement typical of non-work hours (or, at

\footnotetext{
${ }^{1}$ Both the quotations between brackets and the indented quotations are direct translations of excerpts of the testimony of Portuguese workers interviewed in Portugal, Spain or France as part of the research presented here.
} 


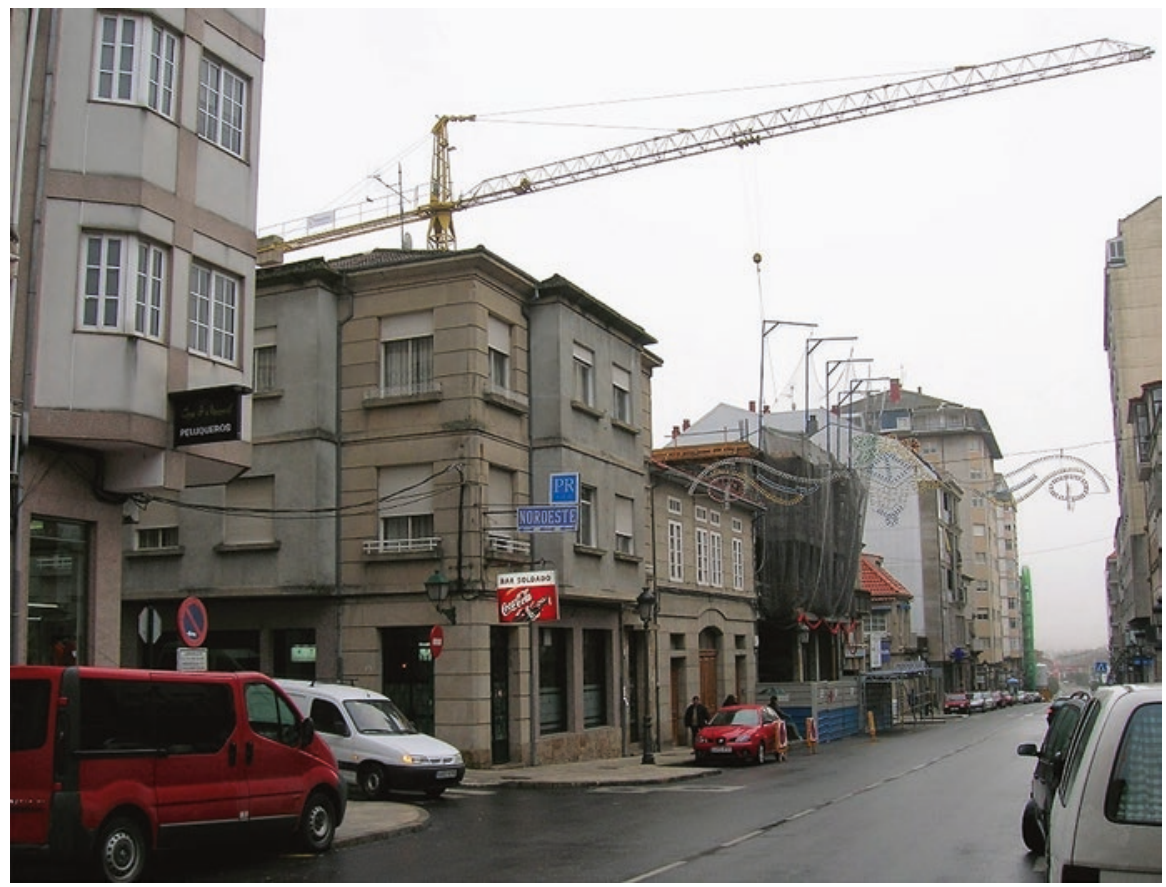

Fig. 8.3 "Pensão Noroeste" and "Bar Soldado", in O Carballiño, Galicia, Spain, where a team of Portuguese construction workers was staying, in January 2008. (Photo: João Queirós)

best, the endogamous sociability within the "team"), and the austerity in consumption throughout the working week all define these migrants' range of probable experiences during their time in Spain. The weekends they spend back in Portugal, on the other hand, provide an opportunity for restoring self-esteem, for the unrestricted use of time ("doing nothing"; "going for a walk"; "sleeping"), for the conspicuous spending of money ("spending all the money on booze"; "going out with the lads here"), and for forms of socialising that had been temporarily interrupted or suspended ("spending time with the family"; "talking freely") - they thus enable migrants to engage in what Moodie $(1991,29)$ calls "practices of personal integrity" (Fig. 8.3).

The alternation typical of this bulimic pattern of appropriating time and space is indelibly etched in minds and bodies: "the imaginary, here, becomes body with biography" (Comaroff and Comaroff 1992, 55). Only if we remain open to understanding these workers' objectively unstable and contradictory status can we resist the impression of ambiguity, bad faith or ineptitude transmitted by their often duplicitous discourse, and attend to the conditions of possibility and reasonableness of the migrant's vision of the world - of his world.

The opacity of the personal consequences of migration is reinforced by migrants' internalisation and naturalisation of experiences of exploitation and domination. By contributing to the impression that this is an exceptional period or a period of respite 
("this is just until I get my life back on track"; "I was living a difficult situation and then this opportunity arose"), the transitoriness of this type of migration helps deflect attention away from the conflicts attributable to power structures. It disguises these conflicts by depicting them as specific to a defensive sacrifice - as operating to restore the harmony of collective and personal existence by "establishing or re-establishing the limits, frontiers and frames legitimately constitutive of these structures of society and culture within which an ordered life can be lived" (Turner 1977, 215). This type of migration emerges as an "opportunity" that is of course both accessible and acceptable, but only for workers able and willing to see it as an effective way to cope simultaneously with necessity ("a guy needs money to pay his dues, to buy his things") and with the imperative of maintaining the social honour of the virtuous man ("walking tall"; "I could stay out of a job but that's even worse"; "I always liked to work"). Under these conditions, the mental and physical costs of work are reinterpreted using the logic of masculine stoicism and virtuosity ("many can't stand it") and justified by the financial compensation it brings ("as long as they pay me at the end of the month...").

De-justification is, however, the most powerful means of justification. The inertia of incorporated structures - which are transmuted physiologically and practically in bodily postures as well as discourses of deference that retranslate collective feelings of inferiority and illegitimacy ("you're in a country that's not yours"; "it's not they who have to adapt to you, it's you who has to adapt to the system") - explains how these workers help realise in everyday life the asymmetries of power present in the social conditions that lie at the root of their schemata of action and thought. The interiorisation of social inequalities - in the form of principles of classification (and hierarchisation) of behaviours, attitudes and appearances - inscribes the moral and physical violence experienced daily in the workplace ("you're in pain"; "you work till you drop dead"; "it was degrading"; "they don't respect anyone") within the order of the "normal" and even of the "deserved". These principles come to function as a "natural" sense of reality: "Because of these perceptions, the migrant body is seen as belonging effectively to the position that it occupies in the system which has meanwhile led to its deterioration" (Holmes 2006, 1787; see also Holmes 2013, ch. 4; Wacquant 2005). In Pedro's words:

The easier, lighter work - it was them [the Spanish workers] who would do it and then... That happens but... In fact, I didn't tell you that, but, for me, for us, that was normal. I think it was good for us things were that way. You want to know why? That way you could prove to the overseer you really knew how to do things - and that way you were able to gain his respect. That was the thing that mattered there.

As the product of naturalised power relations, subordination is confirmed by the apparently spontaneous actions and words of the migrants themselves. As Ong $(1987,3)$ tells us: "The dominant meanings and practices shape the substance of everyday experiences: our expectations, meanings and lived practices constitute and are constituted by our sense of social relations and reality". The effect of evidence of reality ordinarily determines the unquestionable nature of the social world. 
For migrant workers such as those described here, the long-term experience of hard labour, difficult social relations and harsh conditions reinforces common personal and collective beliefs about the unpredictability and even the malevolence inscribed in one's "fate" ("you have to be lucky"; "no one could have guessed what would happen"; "five minutes before and it would have been me, five minutes later and it happened to my colleague"). This long-term experience also tends to produce a self-image of vulnerability to the harshness of reality, aggravated by one's seeming invisibility and insignificance in the eyes of others ("no one respects you"; "they don't give a damn"; "you're just a number"; "from the moment you stop being useful to the company, you become disposable"). Workers' reduction to sheer economic value is linked to their loss of symbolic recognition, producing a loss of self-worth.

\subsection{Facing the "Crisis in Spain"}

As in many other countries, the eruption in Spain of the 2008 "financial and economic crisis" had immediate repercussions for the Portuguese migrants working there - particularly in construction and related sectors. The number of Portuguese workers entering Spain dropped from 27 thousand in 2007 to 17 thousand in 2008; and in the following years this trend only deepened, at least until 2014 (see Fig. 8.1). Specialists talk of a real "collapse" in Portuguese migration to Spain during this period (Pires et al. 2014, 47) - a "collapse" that was inevitably related to the sharp decrease in low-skilled circular and permanent emigration that resulted from the post-2007 slump in the Spanish construction industry, which generated a loss of around 1 million jobs (Byrne 2011; see also Monteiro 2014b). ${ }^{2}$

Although Spain may have lost its importance as a destination for Portuguese migrant workers, the number of Portuguese temporarily or permanently leaving their home country did not decrease. As a matter of fact, between 2008 and 2013, Spain was the only major European destination that witnessed a decline in the number of individuals coming from Portugal. Although it remained one of the most significant receiving countries (the fifth in 2014), Spain saw other European countries, such as Luxembourg, Switzerland, Belgium, the UK, France and Germany, increase (or regain) their relative weight as destinations for Portuguese

\footnotetext{
${ }^{2}$ Between 2007 and 2008, there was a decrease of around 20 thousand registered Portuguese workers in the Spanish construction sector $(-27 \%)$. The total number of Portuguese construction workers registered for Spanish social security decreased by $17 \%$, with a drop of $-40 \%$ in the construction sector and $-26 \%$ in mining and mining-related activities. Nevertheless, the percentage of Portuguese construction workers registered for Spanish social security was still very high: $25 \%$ of the total. Unemployment among Portuguese workers also increased dramatically during this time, especially among construction workers. Of the 15,713 total Portuguese workers registered in unemployment offices in Spain, more than 6 thousand (around 40\%) were construction workers. Between 2007 and 2008 the number of construction workers registered in Spanish unemployment offices rose 233,5\% (OEFP/OOSPEE 2009, 21-27).
} 


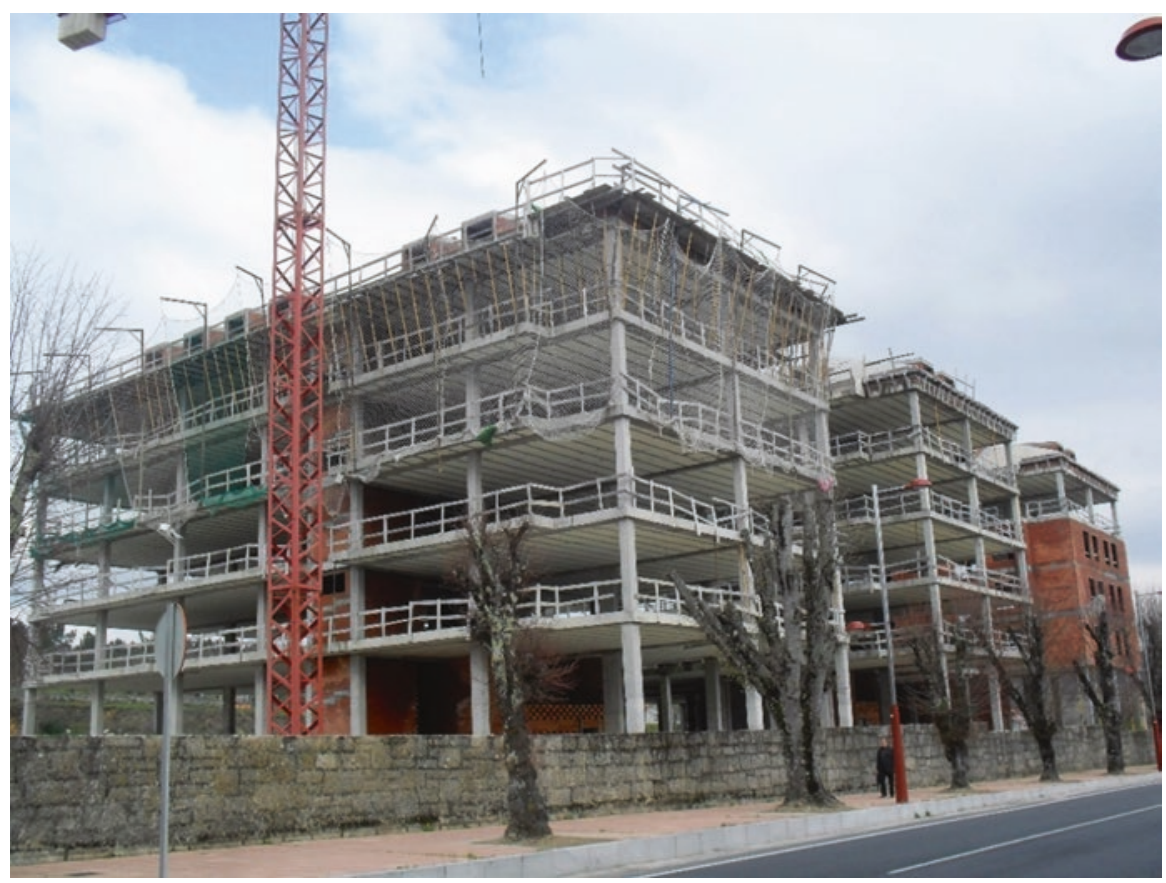

Fig. 8.4 One of many abandoned construction sites, in O Carballiño, Galicia, Spain, in 2013. (Photo: João Queirós)

working class migrants (on this point see Marques and Góis 2014; Observatório da Emigração 2015) (Fig. 8.4).

The dramatic alteration of Portuguese construction workers' prospects for professional and social integration in Spain resulted in their adopting one of the following three main alternatives: (i) returning to Portugal and transitioning to inactivity (especially for older workers), to unemployment, or eventually to employment in a different sector (with or without future re-emigration); (ii) transitioning to permanent residency in Spain - if employed or on unemployment benefits - often combined with a move to a more economically dynamic region; (iii) maintaining a career in the construction sector while diversifying and extending their geographical mobility following the multiplication of Portuguese (and Spanish) construction companies' business locations. 


\section{5 "Old Emigrants, New Emigrants": The Reconfiguration of Work-Related Mobility and Portuguese Working- Class Migrants' Experience in France}

\subsubsection{The European Construction Field and the Reconfiguration of Work-Related Mobilities}

As Monteiro (2014b, 15) emphasises, the Portuguese construction sector's integration into the European market has been fast-tracked by the regressive economic situation of recent years, which has encouraged companies to turn to the external market in various different ways, broadening the geographical scope of their operations and thus opening up new mobility pathways for Portuguese construction workers.

The reconfiguration of work-related mobility in the construction sector is inextricably associated with the ongoing institutionalisation of an integrated European economic space in which construction companies operate and compete. This institutionalisation is advancing due to developments in legal integration; to the progressive liberalisation of markets; to the creation and consolidation of new statutes for workers, such as posted workers; to corporate concentration and restructuring, and to the rise of new economic mediators, among other factors. It has helped to enlarge and consolidate the transnational economic and social space of the migrant condition (Bosch and Philips 2003; Monteiro 2014b).

Although it has opened up new prospects for Portuguese construction workers wiling to avoid unemployment or looking for better jobs and especially better wages, the institutionalisation of an integrated European construction sector and the (imperfect) unification of the European labour market have also brought with them uncertainty and risk. The persistently unequal legal and regulatory frameworks that can be found within Europe - as well as tendencies towards the liberalisation and individualisation of contracts, the segmentation of labour markets and the lowering of wage standards and working conditions (Monteiro 2014b) - have raised new questions for the study of working class migration in Europe.

In Portugual's case - which in a certain sense may be considered unique in western Europe because of the country's long-term status as a provider of low and semiskilled workers to central and northern European economies - there have been clear changes to the main characteristics and patterns of working-class emigration. Aside from the typically circular, volatile character of current working-class Portuguese emigration - which is particularly visible in the construction sector, and makes it substantially different from previous, typically permanent, emigration - the reconfiguration of work-related mobility in recent years has deeply affected the everyday life and experiences of working class migrants. 


\subsubsection{From "Double-Pole Communities" to "Double-Pole De-structuring"?}

Focusing on construction workers, Pinto $(1999,21)$ has noticed how the threat of unemployment - whether short-term or long-term -, wage relations instability, and the compulsive flexibility of productive processes and management strategies all frequently lead to "a decrease not only of the exigency levels (both objective and subjective) regarding working conditions and increasing production rhythms, but also of self-esteem and self-confidence". This results in "the disruption of group solidarities, without which consciousness of labour issues and subsequent collective action are barely attainable". Under conditions of economic flexibility and the everyday uncertainty of mobile, unpredictable work trajectories, the socialising role of work is undermined, and workplaces can become places of "identity destructuring", rather than identity-formation (Pinto 1999, 21-22). This fact is especially visible today, since construction workers are increasingly exposed to job instability and constant socio-geographic displacement. By living as contemporary "nomads" of a kind and having to cope with the risks associated with this condition, circular migrants and international commuters in the construction sector may suffer from what Michel Pialoux, referring to the effects of economic flexibility, calls "existential anxiety" (quoted in Pinto 1999, 22; see also Queirós 2010).

This pattern of migration, work, and everyday life clearly differs from that which could typically be found in eastern France in the 1960s and 1970s, when many thousands of low-skilled Portuguese workers arrived in the area to work in various sectors, and particularly in the Peugeot factories. With job contracts secured by a formal agreement between French and Portuguese authorities, these soon-to-be automotive industry workers were eventually able to establish themselves in the Montbéliard area, in the Bourgogne-Franche-Comté region, where they developed their careers, raised their families, and (re)constructed community ties and a sense of belonging (Fig. 8.5).

Contrasting with this social setting, working class migrants arriving in the region in recent years are typically industrial or, more commonly, construction workers with short-term contracts involved in circular migration who quickly move on to other places. Although there are occasional reports of malaise and competition between fellow-nationals, established migrants ("the old") tend to talk of a "generation" of Portuguese migrants ("the new") who simply "pass through" the area, and are often "almost invisible". These two very different "generations" of Portuguese migrants are not simply different generations in terms of age, but are also the product of different sociological modes by which working class migration is generated (Monteiro 2014b). These different modes result from different stages and configurations of state policies, economic settings, company strategies, and conjunctures in both departure and receiving countries.

In contrast to what typically occurred in the traditional destinations of Portuguese permanent emigration in central and northern Europe - where it was possible to 


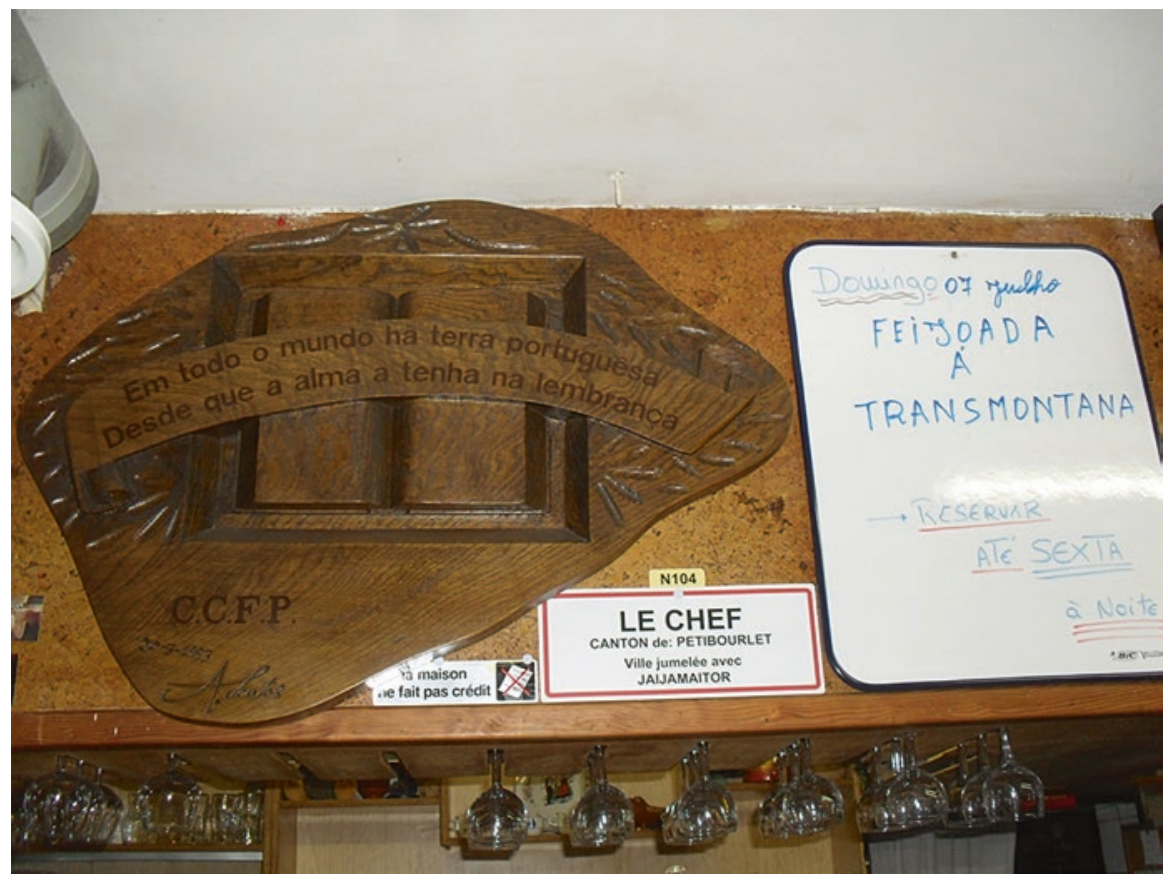

Fig. 8.5 "All around the world there is Portuguese land as long as the soul has it in remembrance". In a Portuguese club in Mulhouse, Bourgogne-Franche-Comté, France, 2013. (Photo: João Queirós)

observe the steady constitution of what Rocha-Trindade (1976) termed "doublepole communities" - the transnational social space created by Portuguese construction workers' circular migration seems to be one in which social processes of double-pole de-structuring have unfolded, rather than the reconstruction of meaningful and durable relations through which migrants' social ties can be reinforced. In fact, under current conditions, while work and geographical trajectories become more individualised and uncertain, migrating construction workers seem increasingly to get trapped in the vicious circle of over-investment in work and interactional confinement: in their multiple, temporary destinations, it is very difficult to invest in the building and consolidation of solid social relations and renewed social networks; and back in their places of origin, social ties tend to weaken and life becomes increasingly atomised.

Acknowledgments and Funding The author would like to thank the Secretary of State for Portuguese Communities for funding the research presented in this chapter (project "Recent emigration trends in Northwest Portugal: the case of construction workers"). The preparation of the final version of this text also benefited from funding from the Portuguese Foundation for Science and Technology, through the Institute of Sociology of the University of Porto (Unit UID/ SOC/00727/2013). The author would also like to thank Cláudia Pereira and Joana Azevedo for their patience and support. 


\section{References}

Bosch, G., \& Philips, P. (Eds.). (2003). Building chaos. Regulation and deregulation in the building industry. London: Routledge.

Bourdieu, P. (1994). Stratégies de reproduction et modes de domination. Actes de la Recherche en Sciences Sociales, 105, 3-12.

Bourdieu, P., \& Sayad, A. (1964). Le déracinement. Paris: Les Éditions de Minuit.

Burawoy, M. (1976). The functions and reproduction of migrant labor: Comparative material from Southern Africa and the United States. American Journal of Sociology, 81, 1050-1087.

Byrne, J. (2011). Spain: The single market in practice? CLR News, 1/2011, 25-33.

Comaroff, J., \& Comaroff, J. (1992). Le fou et le migrant. Actes de la Recherche en Sciences Sociales, 94, 41-58.

Fitzgerald, D. (2006). Towards a theoretical ethnography of migration. Qualitative Sociology, 29(1), 1-24.

Holmes, S. (2006). An ethnographic study of the social context of migrant health in the United States. PLoS Medicine, 3(10), 1776-1793.

Holmes, S. (2013). Fresh fruit, broken bodies. Migrant farmworkers in the United States. Berkeley: University of California Press.

Marcus, G. (1995). Ethnography in/of the world system: The emergence of multi-sited ethnography. Annual Review of Anthropology, 24, 95-117.

Marcus, G. (1998). Ethnography through thick and thin. Princeton: Princeton University Press.

Marques, J. C., \& Góis, P. (2014). A emigração portuguesa contemporânea e o estado: uma nação dispersa, um estado longínquo. População e Sociedade, 22, 55-71.

Monteiro, B. (2014a). Frágil como o mundo. Etnografia do quotidiano operário. Porto: Edições Afrontamento.

Monteiro, B. (2014b). Portuguese construction workers in Spain: Situated practices and transnational connections in the European field of construction. CLR News, 2/2014, 8-32.

Monteiro, B., \& Queirós, J. (2009a). Entre cá e lá. Notas de uma pesquisa sobre a emigração para Espanha de operários portugueses da construção civil. Configurações, 5/6, 143-173.

Monteiro, B., \& Queirós, J. (2009b). Homens duros, vidas frágeis. Uma etnografia da experiência do trabalho migrante na construção civil em Espanha. Actas do X Congresso Luso-AfroBrasileiro de Ciências Sociais, 5/6, 322-328.

Monteiro, B., \& Queirós, J. (2010). Pela estrada fora. Apontamentos sobre a génese social da migração pendular de trabalhadores da construção civil portugueses para Espanha. In J. M. Pinto \& J. Queirós (Eds.), Ir e voltar. Sociologia de uma colectividade local do Noroeste Português (1977-2007) (pp. 261-271). Porto: Edições Afrontamento.

Moodie, D. (1991). Social existence and the practice of personal integrity: Narratives of resistance on the South African gold mines. African Studies, 50(1), 39-63.

Observatório da Emigração. (2015). Portuguese emigration factbook 2015. Lisbon: Observatório da Emigração/CIES-IUL/ISCTE-IUL. https://doi.org/10.15847/CIESOEMFB2015.

OEFP/OOSPEE. (2009). El mercado de trabajo y la movilidad laboral entre España e Portugal. Sintesis de datos/O mercado de trabalho e a mobilidade laboral entre Espanha e Portugal. Sintese de dados. Lisbon: Observatório do Emprego e Formação Profissional/Instituto do Emprego e Formação Profissional (Portugal)/Observatório Ocupacional do Serviço Público do Emprego Estatal (Spain).

Ong, A. (1987). Spirits of resistance and capitalist discipline: Factory women in Malaysia. Albany: SUNY Press.

Pereira, V. B. (Ed.). (2012). Ao cair do pano. Sobre a formação do quotidiano num contexto (des) industrializado do Vale do Ave. Porto: Edições Afrontamento.

Pinho, F., \& Pires, R. P. (2013). Espanha, OEm country reports (Vol. 1). Lisboa: Observatório da Emigração, CIES-IUL, ISCTE-IUL. https://doi.org/10.15847/CIESOEMCR012013.

Pinto, J. M. (1999). Flexibilidade, segurança e identidades sócio-profissionais. Cadernos de Ciências Sociais, 19-20, 5-37. 
Pinto, J. M., \& Queirós, J. (2008). Estruturas produtivas, escolarização e desenvolvimento no Vale do Sousa. Análise da reprodução da condição social periférica numa região metropolitana portuguesa. Cadernos de Ciências Sociais, 25/26, 309-356.

Pinto, J. M., \& Queirós (Eds.). (2010). Ir e voltar. Sociologia de uma colectividade local do Noroeste Português (1977-2007). Porto: Edições Afrontamento.

Pinto, J. M., \& Queiroz, M. C. (1996a). Qualificação profissional e desqualificação social na construção civil. Cadernos de Ciências Sociais, 15/16, 41-85.

Pinto, J. M., \& Queiroz, M. C. (1996b). Flexibilização da produção, mobilidade da mão-de-obra e processos identitários na construção civil. Sociologia, Problemas e Práticas, 19, 9-29.

Pires, R. P., Pereira, C., Azevedo, J., \& Ribeiro, A. C. (2014). Emigração Portuguesa. Relatório Estatístico 2014. Lisbon: Observatório da Emigração e Rede Migra/CIES-IUL/ISCTE-IUL/ DGACCP.

Queirós, J. (2010). Recent economic performance and changing configurations of workforce mobility in Northwest Portugal: Social consequences of unemployment and the rise of youth emigration. In D. Cairns (Ed.), Youth on the move. European youth and geographical mobility (pp. 95-106). Wiesbaden: Springer/VS Verlag für Sozialwissenschaften.

Queirós, J., \& Monteiro, B. (2016). Trabalhos em curso. Etnografia de trabalhadores portugueses da construção civil em Espanha. Porto: Deriva.

Rocha-Trindade, M. B. (1976). Comunidades migrantes em situação dipolar: análise de três casos de emigração especializada para os EUA, para o Brasil e para França. Análise Social, XII(48), 983-997.

Turner, V. (1977). Sacrifice as quintessential process - Prophylaxis or abandonment? History of Religions, 16(3), 189-215.

Vertovec, S. (2007). Circular Migration: The way forward in global policy?. Working Papers of the International Migration Institute, 4.

Vidigal, I. (2016). Emigração portuguesa para Espanha volta a crescer. Observatório da Emigração. http://observatorioemigracao.pt/np4/5417.html. Accessed in July 2016.

Wacquant, L. (2005). Carnal connections: On embodiment, apprenticeship, and membership. Qualitative Sociology, 28(4), 445-474.

Wacquant, L. (2016). A concise genealogy and anatomy of habitus. The Sociological Review, 64, $64-72$.

Open Access This chapter is licensed under the terms of the Creative Commons Attribution 4.0 International License (http://creativecommons.org/licenses/by/4.0/), which permits use, sharing, adaptation, distribution and reproduction in any medium or format, as long as you give appropriate credit to the original author(s) and the source, provide a link to the Creative Commons licence and indicate if changes were made.

The images or other third party material in this chapter are included in the chapter's Creative Commons licence, unless indicated otherwise in a credit line to the material. If material is not included in the chapter's Creative Commons licence and your intended use is not permitted by statutory regulation or exceeds the permitted use, you will need to obtain permission directly from the copyright holder.

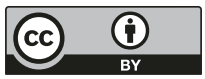

